\title{
Urdimento
}

Revista de Estudos em Artes Cênicas

E-ISSN: 2358.6958

\section{Dispositivos disciplinares: uma análise de projetos artísticos na prisão}

Eliana Doraci da Silva Dayane Vicente de Moraes

\section{Para citar este artigo:}

SILVA, Eliana Doraci da Silva; MORAES, Dayane Vicente de. Dispositivos disciplinares: uma análise de projetos artísticos na prisão. Urdimento, Florianópolis, v. 3, n. 39, nov./dez. 2020.

DOI: http:/dx.doi.org/10.5965/14145731033920200124 
Dispositivos disciplinares: uma análise de projetos artísticos na prisão

\author{
Eliana Doraci da Silva ${ }^{2}$ \\ Dayane Vicente de Moraes $^{3}$
}

\begin{abstract}
Resumo
Este artigo objetiva identificar projetos artísticos nos presídios masculinos de regime fechado no município de Campo Grande, estado de Mato Grosso do Sul, e compreender o uso desses projetos como dispositivo disciplinar da escola no ambiente prisional. Por meio dos referenciais foucaultianos busca-se tratar de problemáticas e tensões que emergem da disciplina ao corpo desses sujeitos. Verifica-se que o artesanato surge consideravelmente nas atividades e propostas de reinserção do sujeito para além dos muros da prisão, sendo utilizado pela instituição como ferramenta para ocupação do tempo do indivíduo, sem valorizá-lo como artista capaz de despertar novos olhares.
\end{abstract}

Palavras-chave: Prisão. Artesanato. Instituição. Disciplina.

Disciplinary devices: an analysis of artistic projects in prison

\begin{abstract}
This article describes artistic projects inside prisons in the city of Campo Grande, state of Mato Grosso do Sul (MS), and examines the use of these projects as disciplinary devices of the school inside the prison environment. Using Foucault, the article addresses problems and tensions that emerge from discipline in the bodies of incarcerated subjects. Artistic practice plays a significant role in the process of building an identity for incarcerated people beyond the prison's walls, but it is also used by the institution as tool for keeping incarcerated people occupied, without valuing them as artists who are capable of growth.
\end{abstract}

Keywords: Prison. Project. Institution. Discipline.

${ }^{1}$ Correção e revisão do texto: Profa. Juliana de Moura dos Santos. Graduada em Letras - Língua Portuguesa e Língua Inglesa. UNIDERP-MS.

2 Discente do Curso de Mestrado em Educação, Programa de Pós-Graduação em Educação (PPGEDU) da Faculdade de Educação (FAED), da Universidade Federal de Mato Grosso do Sul (UFMS), vinculada ao Grupo de Estudos e de Investigação Acadêmica nos Referenciais Foucaultianos (GEIARF), Linha de Pesquisa Educação, Cultura e Sociedade. Orientador: Prof. Dr. Antônio Carlos do Nascimento Osório. edsilva71@uol.com.br

3 Discente do Curso de Mestrado em Educação, Programa de Pós-Graduação em Educação (PPGEDU) da Faculdade de Educação (FAED), da Universidade Federal de Mato Grosso do Sul (UFMS), vinculada ao Grupo de Estudos e de Investigação Acadêmica nos Referenciais Foucaultianos (GEIARF), Linha de Pesquisa Educação, Cultura e Sociedade. Orientador: Prof. Dr. Antônio Carlos do Nascimento Osório. day_moraes15@hotmail.com. 
Dispositivos disciplinarios: un análisis de los proyectos artísticos en la prisión

\section{Resumen}

El objetivo de este artículo es identificar proyectos artísticos en prisiones masculinas de régimen cerrado en el municipio de Campo Grande, estado de Mato Grosso do Sul, y comprender el uso de estos proyectos como dispositivo disciplinario de la escuela en el entorno penitenciario. A través de las referencias de Foucault, el objetivo es tratar los problemas y tensiones que surgen de la disciplina al cuerpo de estos sujetos. Se observa que la artesanía emerge considerablemente en las actividades y propuestas de reinserción del sujeto más allá de los muros de la prisión, siendo utilizada por la institución como herramienta para ocupar el tiempo del individuo, sin valorarlo como un artista capaz de despertar nuevas perspectivas.

Palabras-clave: Prisión. Proyectos. Institución. Disciplina. 


\section{Caminhos e inquietações inicias}

O presente artigo busca apresentar a temática da arte e educação na prisão a partir do mapeamento das produções artísticas realizadas no interior das unidades penais masculinas de regime fechado no município de Campo Grande, estado de Mato Grosso do Sul (MS) com o objetivo de identificar aspectos artísticos dessas instituições, no que diz respeito ao uso de projetos artísticos como prática e estímulo da pessoa em privação de liberdade após o cumprimento de sua reprimenda e compreender o uso desses projetos como dispositivo disciplinar da escola no ambiente prisional.

A partir das experiências vivenciadas em nossas pesquisas, vislumbramos a possibilidade de mesclar os conhecimentos adquiridos no processo de pesquisa de campo e de observação como forma de compreendermos a importância que o tema ocupa no cenário das prisões sul-mato-grossenses.

Considerando que se trata de pesquisa relacionada ao sistema penitenciário do estado de MS, realizamos levantamento de dados e informações na plataforma da Agência Estadual de Administração do Sistema Penitenciário (AGEPEN), órgão responsável pela administração penitenciária do estado de MS, para identificar os projetos artísticos que são desenvolvidos, pois além de trazer publicações atuais, a plataforma ainda disponibiliza informações sobre quantitativos e gráficos com dados da população carcerária, relação das unidades penais por município, informações sobre trabalho prisional, profissionais penitenciários, dentre outros assuntos.

Inicialmente delimitamos os descritores para busca utilizando os termos: arte, arte e educação e atividades artísticas e priorizamos publicações ocorridas entre os anos de 2015 a 2019 que continham relação com arte, educação ou projetos artísticos no ambiente prisional.

Como resultado do descritor arte e educação encontramos diversos artigos, dentre elas uma quantidade significativa voltada ao artesanato, e selecionamos dez que julgamos estarem mais relacionadas com os termos de busca, sendo eles: "Artesanatos produzidos em presídios da Capital e de Corumbá são expostos ao 
público no Festival América do Sul", "Feira de artesanatos feitos em presídios inicia nesta segunda-feira"; "Arte do mosaico profissionaliza e serve como terapia para reeducandas do presídio feminino de Campo Grande"; "Oficina de artesanato ocupa e profissionaliza detentas no presídio feminino de Campo Grande", "Internos do IPCG participam amanhã de capacitação em técnicas de decoupage e artesanato em barbante"; "Com mão de obra prisional, "Arte com Pneus" contempla a 15a instituição infantil de ensino e realiza desejo de alunos; "De embalagens de frutas a big bags de açúcar, descartes viram produto de moda e utilitários nas mãos de detentas"; "Projeto realizado em presídio ajuda no combate à dengue e leva educação lúdica a crianças"; "Com foco na ressocialização, tradição, cultura e educação são incentivadas em presídios de MS" e "Tecido de Afeto e Cura": Com teatro e poesia, reeducandas da capital descobrem um novo olhar para a educação".

Ao utilizarmos o descritor "arte" a plataforma trouxe praticamente os mesmos artigos apresentados com o termo "arte e educação", inclusive muitos sobre o artesanato, com exceção de alguns sem relação com a arte e que estavam mais voltados para o trabalho prisional. Em seguida incluímos o termo "atividades artísticas", que nos trouxe os mesmos artigos já apresentados anteriormente e uma quantidade significativa de matérias sobre artesanato.

Nosso intuito não foi fazer um levantamento completo na plataforma, mas analisar alguns trabalhos desenvolvidos com a temática arte e prisão, tendo como resultado uma maior predominância por projetos, oficinas e capacitações voltadas ao artesanato, muitas vezes inserido em sala de aula.

Com isso, voltamos nosso olhar para a área educacional existente nos presídios onde mais ocorreram esses projetos, buscando compreender o lugar de onde falamos, quando se trata de artesanato, a instituição penal e escola criada exclusivamente para atender a população carcerária, a Escola Estadual Polo Profa Regina Lúcia Anffe Nunes Betine (Escola Betine), que apresentaremos mais a frente.

Assim, por intermédio de um mosaico de diálogos que expressam saberes diversos, nascem questionamentos voltados ao processo de inserção das atividades artísticas e o indivíduo em privação de liberdade, mediante os discursos 
e o corpo desses sujeitos, tais como: Por que não encontramos atividades mais voltados para o desenvolvimento corporal desses indivíduos como a dança, a ginástica ou algum esporte? Por que as atividades consideradas artísticas são mais individuais e manuais, como o artesanato, a pintura, a construção de brinquedos?

Com inquietações que surgem a partir do olhar em nosso campo de estudo, procuramos construir um descaminho daquilo que vem sendo desenhado e posto como verdade no intuito de provocarmos futuras análises, a partir dos referenciais de Michel Foucault, na busca da compreensão da disciplina e os discursos que envolvem o corpo desses sujeitos, sobretudo quanto às atividades artísticas desenvolvidas no ambiente prisional.

Para tanto, entendemos que se faz necessário apresentarmos breve histórico do sistema penitenciário no estado de Mato Grosso do Sul.

\section{Breve histórico do sistema penitenciário sul-mato-grossense}

A gestão prisional do estado de Mato Grosso do Sul foi instituída em 1o de janeiro de 1979, por meio do Decreto-Lei n. 11 (Mato Grosso do Sul, 1979a) e regulamentada pelo Decreto n. 26, da mesma data (Mato Grosso do Sul, 1979b), com a criação do Departamento do Sistema Penitenciário (DSP), órgão com aspecto jurídico de direito público subordinado à Secretaria de Estado de Justiça e Trabalho, que atualmente recebe a denominação de Agência Estadual de Administração do Sistema Penitenciário (AGEPEN), de acordo com Lei n. 4.640 de 24 de dezembro de 2014, tendo como missão:

Administrar o sistema penitenciário estadual, assegurar a custódia das pessoas privadas de liberdade e/ou monitoradas eletronicamente; executar as penas nos diversos regimes e promover condições para a harmônica integração social do condenado e do internado. (Mato Grosso do Sul, 2014a).

A AGEPEN administra quarenta e dois estabelecimentos prisionais localizados em dezenove municípios do estado de Mato Grosso do Sul e uma conta com uma 
população carcerária de 18.836 pessoas presas, distribuída em unidades penais para o público feminino: nove presídios de regime fechado e dois de regime semiaberto e aberto; e trinta e cinco presídios de regime fechado e 11 de regime semiaberto e aberto para o público masculino (AGEPEN, 2019). Também conta com uma unidade mista de monitoramento virtual, que vigia diuturnamente mais de 1.600 pessoas com tornozeleiras. (Mato Grosso do Sul, 2019).

Segundo Oliveira (2018), a aplicação da tornozeleira é feita por meio de determinação judicial, sendo considerada como pena diversa da prisão, pois permite que a pessoa desenvolva suas atividades profissionais e domésticas normalmente, tendo seus locais de circulação previamente estabelecidos.

A AGEPEN é administrada por um Diretor-Presidente ao qual estão ligadas três Diretorias em suas áreas específicas: Diretoria de Operações - área de segurança e custódia, Diretoria de Administração e Finanças - área de administração e finanças e Diretoria de Assistência Penitenciária - área de assistência penitenciária.

De acordo com o artigo 2º, § 10 e incisos I, II e III da Lei Estadual n. 4.490/2014, os serviços da área de segurança e custódia são pertinentes ao planejamento, a supervisão e a execução da vigilância, da disciplina e do controle social das pessoas em privação de liberdade. Já os da área de assistência penitenciária são relacionados com o planejamento, a supervisão e a execução de perícia. A área de administração e finanças tem como atribuição o planejamento, a coordenação e a administração de materiais, patrimônio, orçamento e finanças. (Mato Grosso do Sul, 2014b).

A Diretoria de Assistência Penitenciária (DAP) da AGEPEN é o órgão responsável pelo ensino, capacitação profissional e demais assistências às pessoas em privação de liberdade e sua estrutura é composta pelas Divisões: de Saúde, Promoção Social, Trabalho e de Educação e Profissionalização, sendo esta última responsável pela organização e promoção de ações voltadas a escolarização e ensino profissional, considerando que "as tentativas para a ressocialização dos homens e mulheres em privação de liberdade passam por uma educação de qualidade e pela capacitação profissional." (Brasil, 2012).

Dentre as atribuições da Divisão de Educação da AGEPEN estão: 
[...] a promoção do estudo, análise e diagnóstico da situação atual sobre a educação nos estabelecimentos penais, apontando indicadores que contribuam para garantir o avanço da oferta de educação à pessoa presa; a elaboração, a execução, o acompanhamento e a avaliação de planos, programas, projetos e ações voltados a educação formal e profissional ao custodiado; a atuação integrada às demais Divisões da AGEPEN-MS, buscando a convergência e complementaridade das ações socioeducativas. (Mato Grosso do Sul, 2015).

Nesse sentido, Silva (2019a) observa que para AGEPEN "a oferta de ensino formal e de cursos profissionalizantes têm sido de grande ajuda na reinserção social dos presos do sistema prisional de Mato Grosso do Sul".

Para a pessoa em privação de liberdade o trabalho dentro de um presídio é valioso, pois o ajuda a reduzir o tempo de condenação, por meio da remição de sua pena, e a ter uma profissão para quando retornar ao convívio com a sociedade fora dos muros da prisão.

A Lei de Execução Penal (LEP), Lei n. 7.210, de 11 de julho de 1984, além de tratar da assistência à pessoa em privação de liberdade, traz a questão da remição da pena pelo trabalho e pelo estudo em seu artigo 126, § 10, incisos I e II:

Art. 126. O condenado que cumpre a pena em regime fechado ou semiaberto poderá remir, por trabalho ou por estudo, parte do tempo de execução da pena.

§ 10 A contagem de tempo referida no caput será feita à razão de: I - 1 (um) dia de pena a cada 12 (doze) horas de frequência escolar atividade de ensino fundamental, médio, inclusive profissionalizante, ou superior, ou ainda de requalificação profissional - divididas, no mínimo, em 3 (três) dias;

II - 1 (um) dia de pena a cada 3 (três) dias de trabalho. (Brasil, 1984).

Além da remição da pena por estudo, a Portaria n. 1/20184, da Primeira Vara de Execução Penal de Campo Grande, estabeleceu e disciplinou a implantação de

\footnotetext{
${ }^{4}$ Segundo informações da assessoria de imprensa da AGEPEN, em Mato Grosso do Sul, a primeira comarca a implantar a remição de pena por meio da leitura foi Paranaíba, em setembro de 2014, com a remição de quatro dias de pena para cada obra lida, limitando-se ao total de 12 por ano. Atualmente, este tipo de remição já está sendo desenvolvida em estabelecimentos prisionais de seis municípios. São os juízes das Varas Criminais de cada Comarca que estabelecem as portarias, explicando a maneira como serão realizados os trabalhos, contudo, a Divisão de Educação/AGEPEN estuda uma forma de padronizar essa remição. (Disponível em: http://www.agepen.ms.gov.br/no-dia-mundial-do-livro-leitura-e-sinonimo-deliberdade-para-quem-esta-na-prisao/).
} 
remição pela leitura. De acordo com o artigo 6이 da Portaria: "A contagem do tempo para fins de remição será feita à razão de 4 (quatro) dias de pena para cada 30 (trinta) dias de leitura”.

O artesanato tem sido forma de expressão de arte e meio para aquisição de uma profissão de pessoas em privação de liberdade durante sua reprimenda, por intermédio de capacitações realizadas em parceria com instituições públicas e/ou privadas e que oportunizam trabalho, renda e redução da pena, sendo utilizado tanto pela escola no ambiente prisional, quanto pelo próprio sistema penitenciário como ferramenta de disciplina e controle.

Percebemos que o que é gerado no processo técnico dessas capacitações como um produto, tem foco no caráter de empreendedorismo adquirido pelo fazer artesanal. Afinal, se a relação é apenas sobre o que é produzido, ou para remissão de pena, não se estabelece o refletir sobre a produção artística.

\section{O caráter disciplinar da escola no ambiente prisional}

A educação por intermédio da instituição, apresenta-se de maneira controlada, estabelecendo uma determinada ordem, sendo viável para a manutenção das relações atribuídas no interior de cada domínio da sociedade, como na prisão. Sendo a instituição um espaço com movimentações voltadas para estabelecer, construir, organizar suas intenções, trazemos aqui alguns dados sobre a escola e a prisão no município de Campo Grande.

No ano de 1998, foi celebrado um convênio entre a Secretaria de Estado de Educação (SED) e o DSP , inclusive com a previsão de cedência de professores, e, pela Deliberação n. 5.178/98 do Conselho Estadual de Educação (CEE/MS) a Escola de Serviços Penitenciários passou a ser uma extensão de ensino supletivo do Centro de Estudos Supletivos Profa. Ignês De Lamônica Guimarães, de acordo com o Plano Estadual de Educação nas Prisões do estado de Mato Grosso do Sul, porém os cursos supletivos foram extintos no ano de 2000 e uma outra forma da política educacional foi implantada. 
[...] com a extinção dos Cursos Supletivos em 2000, conforme Resolução SED n. 1442/2000, a Secretaria de Estado de Educação implantou uma nova política de Educação de Jovens e Adultos, criando também uma nova política educacional para as pessoas privadas de liberdade, passando a funcionar como extensão da Escola Estadual Prof. Carlos Henrique Schrader. (Mato Grosso do Sul, 2015).

Três anos após a implantação deste novo formato da política educacional, foi criada oficialmente a Escola Estadual Polo Prof.a Regina Lúcia Anffe Nunes Betine (Escola Betine), Decreto n. 11.514, de 22 de dezembro de 2003, e por meio da Resolução n. 1.714/2004 foi credenciada "para ofertar Educação Básica, com funcionamento do ensino fundamental e do ensino médio" (Mato Grosso do Sul, 2015, p. 22).

Por se tratar de uma escola com público específico, a estrutura física da gestão da Escola Betine funciona em prédio localizado próximo ao centro do município de Campo Grande, distante das prisões em que se localizam as atividades pedagógicas, distribuídas nas 16 salas de aulas existentes nos presídios do município de Campo Grande, estado de Mato Grosso do Sul (MS).

A Escola Betine é uma unidade de gestão administrativa onde também são planejadas e elaboradas as atividades relacionadas aos alunos custodiados e em cumprimento de medida socioeducativa de internação. Enfatizando que as atividades pedagógicas ocorrem em espaços que estão localizados nas unidades de extensão, assim denominadas, no interior de cada presídio.

O fato das extensões escolares estarem localizadas na parte interna dos presídios evidencia as relações de poder e disciplina existentes para/na oferta da educação, pois a rotina e procedimentos impostos denotam o adestramento dos sujeitos como destaca Foucault (2014, p. 167, grifo do autor):

[...] o poder disciplinar tem por função principal "adestrar"; ou, sem dúvida, adestrar para cobrar e extorquir mais e melhor. Não junta as forças para as subjugar; tenta uni-las para multiplicá-las e utilizá-las em conjunto. Em vez de subjugar uniformemente e em massa tudo o que the está submetido, separa, analisa, diferencia, leva os seus processos de decomposição até às singularidades necessárias e suficientes. [...]. A disciplina "fabrica" indivíduos; é a técnica específica de um poder que vê os indivíduos como objetos e instrumentos do seu exercício. 
Do mesmo modo, pode-se observar que os caminhos que levam o aluno em privação de liberdade até a sala de aula, bem como a rotina diária vivenciada por eles denotam o exercício desse poder disciplinar.

Um exemplo disso é apresentado por Foucault (2014) no regulamento onde consta a rotina da Casa dos Jovens detidos em Paris no ano de 1838, onde podese destacar os artigos n. 22 e n. 23 que tratam da educação daqueles jovens:

Art. 22. Escola. Às 10h40, ao rufar do tambor, os detidos formam filas e entram na escola por divisões. A aula dura duas horas, dedicadas alternadamente à leitura, à escrita, ao desenho linear e ao cálculo.

Art. 23. Às $12 \mathrm{~h} 40$, os detidos deixam a escola por divisões e dirigem-se aos seus pátios para o recreio. Às $12 \mathrm{~h} 55$, ao rufar do tambor, voltam a formar-se por oficinas. (Foucault, 2014, p. 11-12).

A rotina apresentada por Foucault (2014) demonstra a relação de poder da instituição com o sujeito em privação em privação de liberdade e impõe uma disciplina marcada por regras.

Tal regulamento não difere do que foi observado em agosto de 2019 durante visita ao Instituto Penal de Campo Grande (IPCG), um dos presídios pesquisados, pois, conforme informações coletadas, a rotina de um presídio tem início às seis horas da manhã e o café da manhã é servido nas celas entre sete e oito horas.

Após esse horário iniciam-se as atividades diárias e por volta das oito horas da manhã aqueles que estudam começam a ser liberados. Aos poucos, os alunos em privação de liberdade seguem caminhando em fila indiana, acompanhados pelos agentes penitenciários que os conduzem até o módulo de educação. A seguir apresentamos a fachada, a sala de aula e o módulo de educação do IPCG. 
Figura 1 - Fachada do IPCG

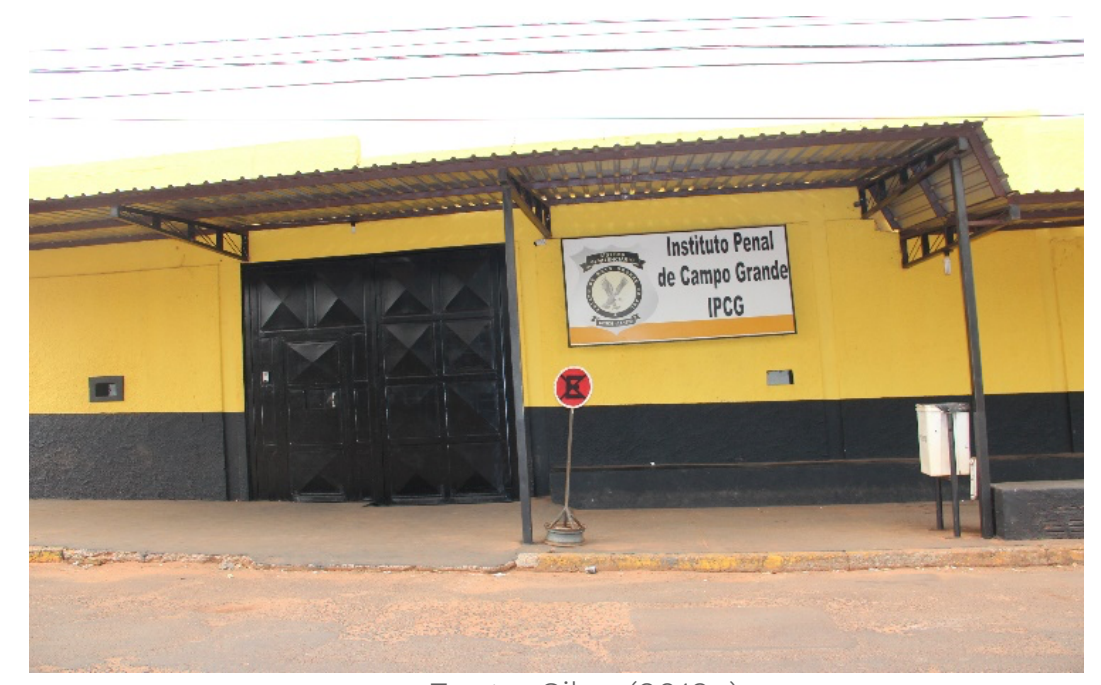

Fonte: Silva (2019a)

Ao nos aproximarmos da instituição penal investigada, conforme figura 1 acima, vislumbramos os altos muros, grandes portões fechados e, mesmo de fora, a presença de vigilância por meio de câmera de Circuito Fechado de TV.

Uma minúscula abertura, que pode ser vista a esquerda da figura 1, se abre após tocarmos o interfone, nos identificarmos e recolherem nossos documentos pessoais com foto. Somente após esse procedimento é que o portão se abre para que possamos adentrar a unidade prisional.

As figuras 2 e 3 abaixo demonstram o ambiente e o espaço que esses indivíduos possuem para a realização das atividades, porém com total controle, pois as atividades não são realizadas ao ar livre limitando-se às salas de aula ou outros espaços fechados, onde ocorre a construção dos trabalhos. 


\section{Urdimento}

Figura 2- Sala de Aula (IPCG)

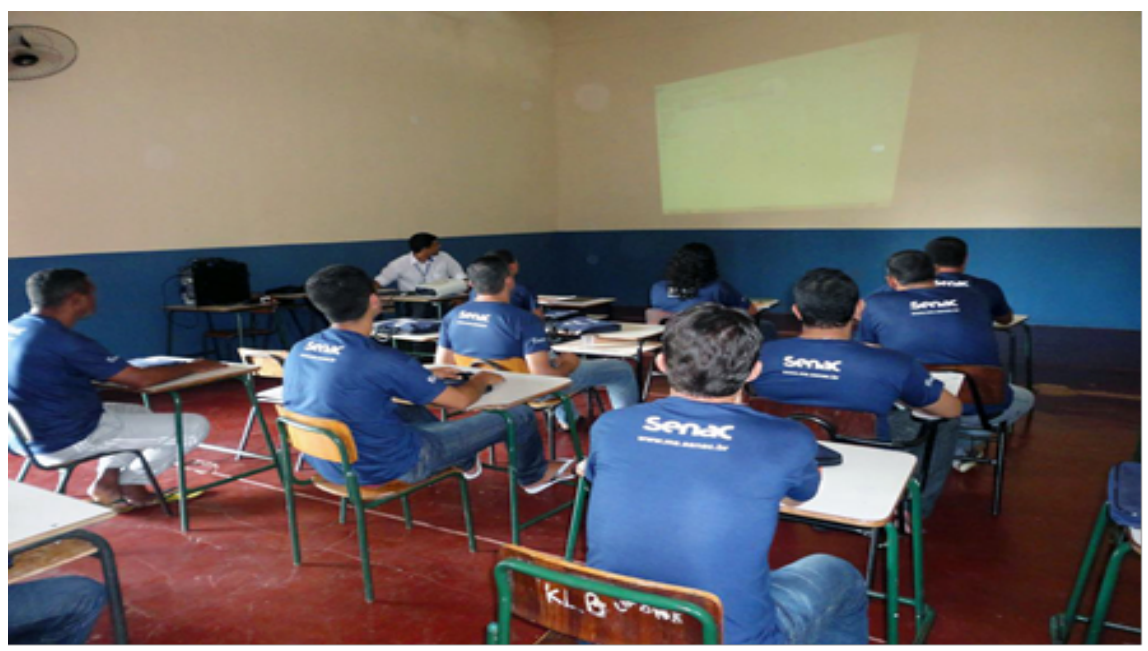

Fonte: Silva (2019b)

A figura 2 apresenta uma sala onde ocorre um curso profissionalizante com alunos em privação de liberdade uniformizados, mas o ambiente como o de uma escola da educação básica: fileiras de carteiras, instrutor à frente, porém cada um no seu espaço, denotando a presença do adestramento e disciplina desses sujeitos.

A maneira como visualizamos o trato para com esses sujeitos, sempre no intuito de manter a ordem, nos leva a refletir que a inclusão das artes cênicas como dança, circo e teatro, levariam esses sujeitos a terem que se portar de outras maneiras, com maior liberdade de seus corpos e possibilidades de criações.

Figura 3 - Módulo de Educação do IPCG

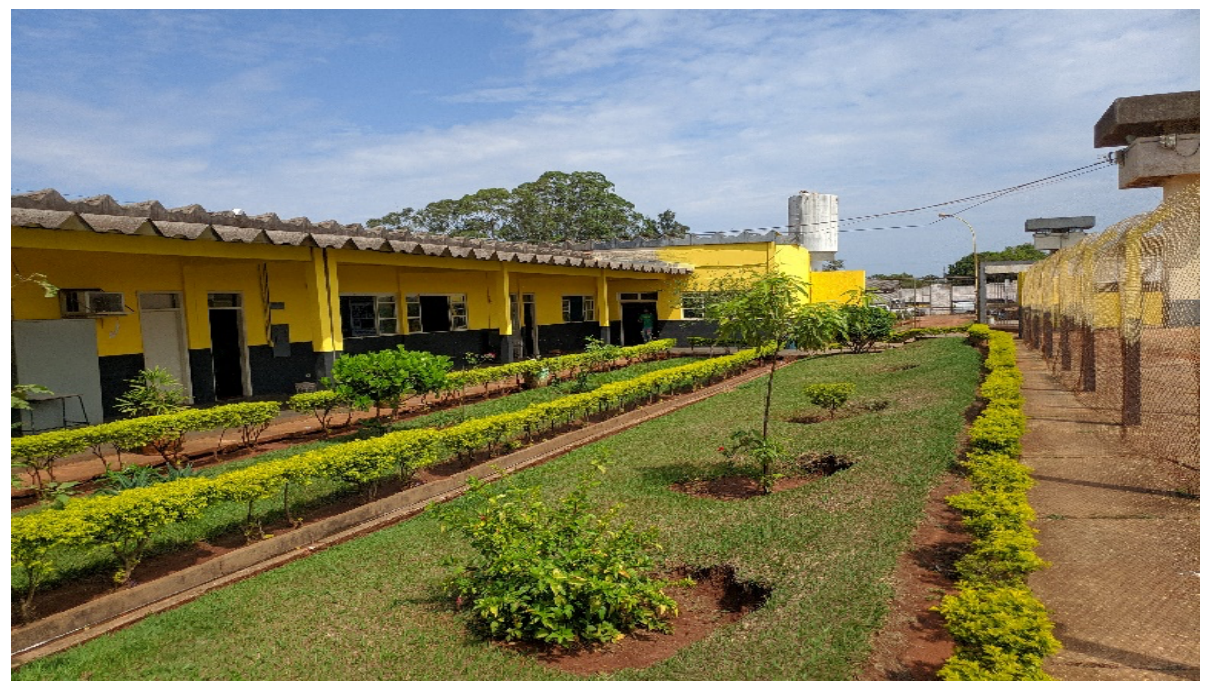

Fonte: Silva (2019a) 
O ambiente externo as salas de aula, como apresentado na figura 3, é reduzido e fechado em sua frente, rodeado por grades e com pouco espaço para até mesmo caminhar, demonstrando que a maneira como a estrutura se apresenta determina o que esses sujeitos podem ou não realizar dentro do ambiente escolar prisional.

Assim, em termos foucaultianos, verificamos que a disciplina e a aprendizagem se relacionam a partir de mecanismos de controle dos indivíduos, pois a disciplina "fabrica assim corpos submissos e exercitados, corpos dóceis." (Foucault, 2014, p. 135).

Nesse sentido, Castro (2016) aponta que em Foucault, encontramos principalmente dois usos do termo "disciplina". Um na ordem do saber (forma discursiva de controle da produção de novos discursos) e outro na do poder (o conjunto de técnicas em virtude das quais os sistemas de poder têm por objetivo e resultado a singularização dos indivíduos. (Castro, 2016, p. 110).

O poder para Foucault "não é uma substância ou uma qualidade, algo que se possui ou se tem; é, antes, uma forma de relação [...]” (Castro, 2016, p. 326). O autor ainda aponta que "segundo Foucault, a palavra que permite captar melhor a especificidade das relações de poder é o termo "conduta". "O exercício do poder consiste em conduzir condutas e dispor a probabilidade." (Castro, 2016, p. 327).

A educação escolar no sistema prisional é tida pelos profissionais como um dispositivo disciplinar, pois entendem que um de seus papeis é controlar a conduta das pessoas em privação de liberdade. Com isso, verificamos que a prisão e a escola impõem uma rotina rígida marcada por relações de poder que adestram o indivíduo por meio de mecanismos e critérios de seleção, disciplina e vigilância.

Também há de se considerar os espaços educacionais das unidades penais, pois estes não atendem um princípio básico da Constituição Federal (1988) "educação direito de todos", uma vez que nem todos os interessados em frequentar a sala de aula, onde são realizadas as atividades artísticas, podem fazêlo, seja por questões disciplinares, por falta de vaga ou por questões de segurança, o que denota o controle e as relações de poder existentes.

Entendemos que é importante questionarmos se a educação escolar nas prisões é um direito ou uma assistência, pois até a legislação que a regula ora a 
traz como direito, ora como assistência, o que nos leva a crer que dentro dessa instituição penal e escolar podem ser realizadas atividades artísticas e culturais. Assim, a instituição segue a programação do calendário escolar e dos projetos educacionais/culturais propostos anualmente e a partir daí verificamos a presença das artes cênicas como a dança e o circo nas apresentações culturais.

Para tanto, há que se considerar as condições e possibilidades para a escolarização da pessoa em privação de liberdade e verificar se o discurso da ressocialização da pessoa em privação de liberdade tem relação com a educação, na tentativa de demonstrar que a escola do sistema prisional deve ser mais que um dispositivo de poder, de adestramento do corpo, ela deve ser uma instituição que desperta a vontade de saber e de criação.

Consideramos que no processo de desenvolvimento individual do sujeito, o encontro com as artes cênicas instiga seu modo de pensar e de interagir, provocando relações que afetam sua realidade.

Nesse sentido, a seguir, apresentamos os aspectos artísticos relacionados ao corpo desses sujeitos em privação de liberdade.

\section{Corpo/Sujeito: aspectos artísticos}

A arte na sociedade é vista como uma manifestação da cultura humana construída ao longo da história, tendo surgido a partir da prática principal do homem que é o trabalho, possibilitando várias sensações no indivíduo, sendo possível libertar-se do cotidiano da vida. (Assumpção, 2014). Deste modo, é relevante trabalhar de maneira consciente a arte na educação no processo humanizador do indivíduo.

Consideramos importante que o indivíduo se aproprie do que é construído pela humanidade por isso, o ensino dos aspectos artísticos é algo fundamental para a formação humana em todos os campos, contudo a forma como é apresentado e trabalhado no contexto prisional, é diferenciada levando em conta a especificidade do seu público.

O que encontramos é um espaço permeado com foco na disciplina e ordem, que dificulta a realização dessas atividades, sendo que as atribuições em relação 
as instituições e sua rede de conexões se configuram nesse ambiente garantindo a obediência, mas também o controle dos gestos, das atividades e do tempo dessas pessoas em privação de liberdade.

Por isso nossa inquietação sobre a maior predominância em atividades relacionadas a arte dentro dos presídios serem com pouca movimentação, como o artesanato, e mais voltadas à capacitação profissional e geração de renda.

Observamos que as atividades artísticas realizadas pelas pessoas em privação de liberdade, em sua maioria, são voltadas para a ressocialização, como apontado no discurso da diretora da Escola Betine, citado por Santinoni e Oliveira (2017):

Segundo a diretora da Escola Polo "Regina Betine", Cacilda Inácio da Silva, as festas juninas acontecem em todos os estabelecimentos penais que possuem extensão escolar. "A ideia central é trazer para dentro dos presídios, os tradicionais festejos presentes no calendário cultural de todo o Brasil, isso os motivam e auxiliam na ressocialização", enfatiza a diretora. (Santinoni e Oliveira, 2017).

Contudo, não vemos foco nas práticas que envolvem mais o sujeito propriamente dito.

Ocasionalmente a dança é trabalhada nas festividades programadas no calendário escolar. Não é algo ruim, porém se fosse planejada no intuito de enriquecer esses indivíduos, traria benefícios duradouros e transformadores.

Nesse sentido, o que vemos é a utilização do corpo desses sujeitos como dispositivos, que ocupam e mostram o resultado do trabalho desenvolvido na escola por meio da encenação e espetacularização.

Diante do exposto, questionamos como esses momentos de aprendizado e criação artística são vistos pelas pessoas em privação de liberdade. Seria para elas uma fuga da realidade? Ou somente uma maneira de se capacitar e ganhar dinheiro quando estiverem em liberdade? Essa experiência proporcionada para alguns, de maneira sucinta e em forma de trabalho pode ser capaz de levar o indivíduo a ver o mundo de outra maneira? Cabe-nos ressaltar que segundo relato de funcionários penitenciários, é necessário passar por um processo de seleção e avaliação da ficha disciplinar para estar apto a participar dos projetos e frequentar a escola. 
$\mathrm{Na}$ medida em que as análises sobre a arte passam por intermédio de condições dos sujeitos que produzem saberes diversos, verificamos que estes se afastam de ser o que deveriam ser e entram num jogo de relações, sendo representados socialmente pela instituição que exerce o controle dos saberes e poderes.

Diante disso, há uma junção do corpo com práticas e saberes, que não é mero corpo físico, mas sim constituinte de elementos culturais que integram esse corpo, a partir de relações entre os sujeitos ao longo de sua existência. Ainda que rodeado de normas e regulamentações “[...] um poder que se pensa como regulação que só pode se efetuar através de e apoiando-se na liberdade de cada um, creio que isso aí é uma coisa absolutamente fundamental" (Foucault, 2008a, p. 64). Nesse sentido, esse poder é dissolvido, não há uma concentração específica, o intuito é ver como se operacionaliza.

Essa disciplina opera o poder sobre os sujeitos na forma como a prisão atua em seu meio de convivência, regulando seus movimentos e comportamentos, não utilizando o movimento artístico cênico como possibilidades de refletir, criticar, dar liberdade de pensamento e possibilitar criações artísticas e corporais.

Para Foucault (2015), os sujeitos se articulam e vivenciam práticas que constituem seu cotidiano. Esses saberes são decorrentes das relações de poder que permitem um controle dos sujeitos no seu espaço e tempo. Nessa grande teia de saberes e poderes que se exteriorizam na posição que esse corpo ocupa no espaço da sociedade. Assim, "é pelo estudo dos mecanismos que penetraram nos corpos, nos gestos, nos comportamentos, que é preciso construir a arqueologia das ciências humanas." (Foucault, 2015, p. 242).

Nesse sentido, o Estado tem grande papel na intervenção para a construção dessas práticas que são regradas mediante a utilidade ou não de seus efeitos. Relações ajustadas de governo que se acercam da cultura, da educação, como uma forma de instituir utilidades econômicas para um sistema produtivo.

Foucault (2008b) quando trata da utilidade, usa como ancoragem a razão governamental.

Esse ponto de ancoragem é a elaboração do poder público e a medida 
das suas intervenções indexadas aos princípios de utilidade. Troca, do lado do mercado - utilidade, do lado do poder público. [...] é um jogo complexo entre os interesses individuais e coletivos, a utilidade social e o benefício econômico. (Foucault, 2008b, p. 60-61).

Com isso, essas práticas movimentam-se por interesse da sociedade. Não queremos generalizar, mas sim olhar esses diálogos que envolvem as atividades artísticas de modo que tal movimento seja preservado da forma como está posto.

[...] para Foucault, circula na sociedade como um dispositivo de caráter regulamentador, visando sempre uma ordem disciplinar, se instrumentalizando por diferentes procedimentos controladores, impondo valores (sua adequação) ao corpo e aos acontecimentos coletivos da sociedade, podendo ser aleatórios ou não, mas sempre induzidos. É o que ele denomina de sociedade normalizada - apaziguada de seus conflitos, de suas diferenças, nem que seja por um pequeno espaço de tempo, podendo gerar outros conflitos exigindo outras regulamentações, mas nunca solucionaram a anomalia social, pois em risco está a concentração do poder pelo próprio grupo de domínio. (Osório, 2007, p. 316).

Logo, buscamos esse olhar maior para o corpo e suas práticas, quando se trata do sujeito em privação de liberdade, encontramos o foco maior para capacitação e ocupação de tempo, com discursos voltados para a ressocialização como maneira de inserção no mercado de trabalho. Vemos assim, cursos, projetos, ações voltadas para que esses sujeitos adquiram habilidades voltadas para um modo de produção que possam gerar algum resultado econômico.

Partimos assim, no que concerne o corpo e suas relações de saber e poder, para um processo de problematização dos discursos e práticas de regulação nas instituições e com isso nos situamos sobre o que é essa instituição que recebe atividades artísticas e culturais.

Tarefa difícil, segundo Osório (2010), que ressalta o equívoco de pensarmos a instituição como sinônimo de estabelecimento, de espaço e de ambiente físico, mas, sim, como um conjunto de práticas estabelecidas no exercício do poder em rede, a partir de conjunto de tecnologias que se repetem e legitimam, enquanto ferramentas eficientes de controle.

Segundo o autor, as instituições são encaixadas e organizadas em rituais de 
senso comum, compreendidas por meio de suas funções legitimadas por atributos culturais e sociais. No entanto, para analisarmos as instituições, devemos abandonar explicações simplórias ou os discursos institucionais, para darmos lugar às elaborações decorrentes de práticas sociais. Considerando que:

Nenhuma instituição existe fora do poder ou sem poder. Ela é produzida pela sociedade graças às múltiplas coerções e nela produz efeitos de poder. Cada sociedade tem seu regime de verdade, isto é, os tipos de discursos que ela acolhe e faz funcionar como verdadeiros. (Foucault, 2015, p. 132).

Desse modo, analisar essa dinâmica que envolve a instituição, não é algo fechado, mas rodeado por mecanismos e dispositivos. O corpo aqui não é só pensado como físico, ele é um dispositivo. Falar de dispositivo com Foucault não é algo simples demanda uma intenção. Foucault (2015) afirma que o dito e o não dito compõem o dispositivo, que é, portanto sempre um conjunto heterogêneo de relações. Osório (2019) discorre que os dispositivos envolvem as diferentes maneiras de produções, que incidem sobre o corpo, mas que também o transforma em maquinaria, que produz, além de condições históricas, movimentos jurídicos.

O corpo é um elemento estratégico das políticas, é submetido aos mecanismos disciplinares, porém é necessário levar em consideração que ele emerge de vários dispositivos em funcionamento, sendo modificados nesse grande jogo de relações e discursos, que derivam sentidos não só no exterior dessas relações, mas se volta para nós mesmos, nos moldando, em movimento constante. (Osório, 2018). Desse modo, é necessário pensar nessa materialidade corporal, que se inclina para as forças que circulam sobre esses corpos dentro dessa instituição.

Existem práticas complexas que permeiam a instituição e o corpo buscando correções sociais, a partir de aspectos físicos, artísticos, biológicos e psicológicos. Diante disso, o corpo não possui conhecimento por completo, é alinhado em um conjunto de relações e discursos. (Osório, 2019).

A partir da construção de quem somos e do espaço que ocupamos, a seguir 
apresentamos as atividades artísticas desenvolvidas no ambiente prisional.

\section{Atividades artísticas no ambiente prisional}

Como dito anteriormente, nossa pesquisa identificou que o artesanato é considerado como ferramenta de maior predominância no campo das atividades artísticas no ambiente prisional. Nesse sentido, os projetos culturais e artísticos desenvolvidos pela instituição exploram o uso das atividades manuais como dispositivo de controle, porém, também apresentam outras expressões artísticas como a dança e o circo.

De acordo com relato de uma profissional do sistema penitenciário, no município de Campo Grande, MS, um dos primeiros presídios a oferecer o artesanato como arte e renda às pessoas em privação de liberdade foi o Instituto Penal de Campo Grande (IPCG); unidade penal masculina de regime fechado.

Segundo a profissional, o início das atividades artesanais no IPCG tem origem por meio de duas pedagogas do quadro efetivo da AGEPEN, que durante sua rotina de trabalho passam a orientar e dar dicas à algumas pessoas em privação de liberdade que confeccionavam peças em crochê, barbante, colagem em papel e madeira e escultura em papel machê, argila e epoxi.

A busca por uma ocupação toma proporções tão grandes que entre os anos 2000/2001 as pedagogas solicitam à direção da unidade penal a criação de um setor de artesanato para confecção e guarda das peças produzidas. Nesse período é oferecido às pessoas em privação de liberdade curso de escultura de animais do Pantanal em argila e, então, começam a surgir uma quantidade significativa de onças pintadas, tuiuiús, garças brancas, araras azuis e vermelhas, capivaras, tucanos e outros animais em miniaturas.

A servidora ainda comenta que por meio de parcerias as pedagogas preparam exposição e venda dos trabalhos em uma feira de artesãos na Praça dos Imigrantes. O resultado da exposição é tão significativo que oferecem um espaço permanente na referida praça para venda das peças e materiais produzidos no 
IPCG. Segundo a servidora parte do dinheiro arrecadado com as vendas era utilizado para pagamento da locação do espaço e a outra para aquisição de matéria-prima a ser utilizada para a produção de novas peças.

Desde o ano de 2015 os artesanatos produzidos nos presídios do município de Campo Grande, MS, são expostos e vendidos na Feira do Artesão Livre realizada no Fórum de Campo Grande e em festivais estaduais, nacionais e internacionais, conforme figuras abaixo.

Figura 4 - Feira do Artesão Livre no Fórum de Campo Grande

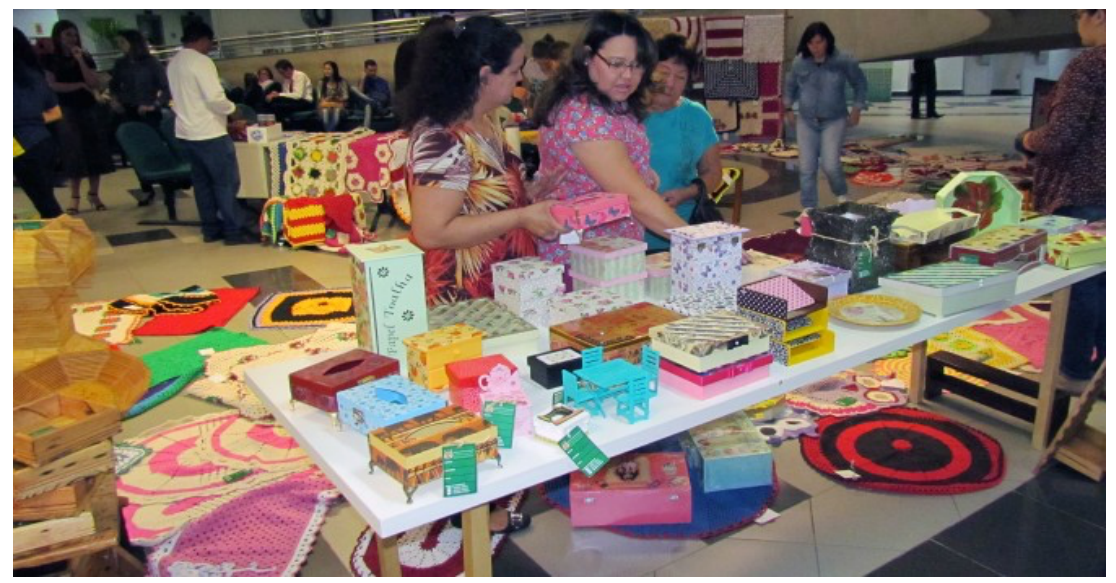

Fonte: Oliveira (2016)

Figura 5 - Exposição no Festival América do Sul (2015)

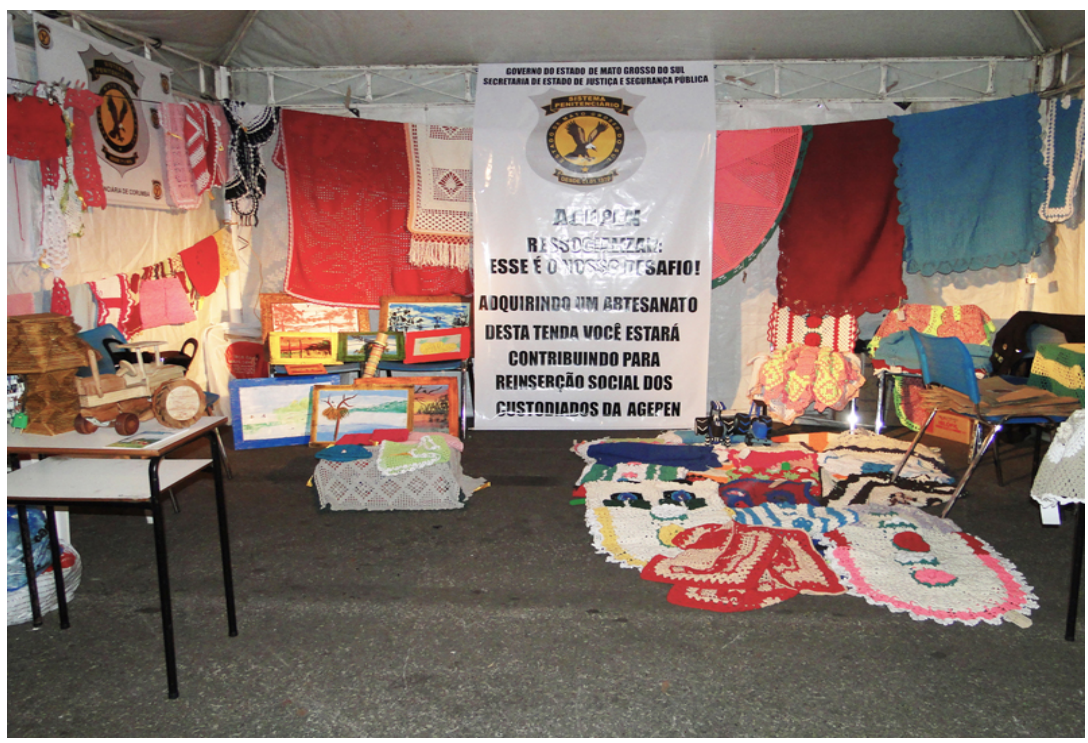

Fonte: Oliveira (2015) 
Atualmente as pessoas em privação de liberdade que trabalham com artesanato no ambiente prisional são registradas no Sistema de Informações Cadastrais do Artesanato Brasileiro (SICAB) com efetivação após o artesão "passar por uma prova de habilidades técnicas, cuja aprovação é da Gerência de Desenvolvimento de Atividades Artesanais da Fundação de Cultura de Mato Grosso do Sul" (Lima, 2015). Após a aceitação do registro os artesãos recebem a carteira nacional do artesão, emitida pela Secretaria da Micro e Pequena Empresa (SMPE), por meio do Programa do Artesanato Brasileiro (PAB).

A Carteira Nacional do Artesão é uma identificação nacional para artesãos e trabalhadores manuais de todo o Brasil. O documento tem abrangência nacional e oferece diversos benefícios, como isenção de imposto ao participar de feiras ou vendas para outros Estados, descontos para compras em alguns estabelecimentos comerciais, possibilidade de comercialização em determinados espaços, como a Casa do Artesão, que só aceitam artesãos com a carteira em dia e possibilidade de tirar nota fiscal na Agência Fazendária. (Lima, 2015).

Diante do que apresentamos, verificamos uma certa predominância e valorização em atividades artísticas que possam gerar renda e mão de obra especializada para o mercado de trabalho. Não vislumbramos o interesse da instituição em fazer desses sujeitos artistas ou tornar seus trabalhos conhecidos no ambiente artístico e sim, mera ocupação de tempo e desempenho em criação de um artesanato para demonstração. Não que essa seja a verdade pronta e acabada, mas que seja possível ter novos olhares para as questões levantadas.

Contudo, também observamos o quanto a criatividade das pessoas em privação de liberdade aflora quando se envolvem nos projetos culturais e artísticos voltados para as artes cênicas propostos na extensão da Escola Betine na unidade penal, conforme as figuras 6,7 e 8 a seguir. 


\section{Urdimento}

Figura 6 - Apresentação alunos do EPJFC encerramento do ano letivo 2016

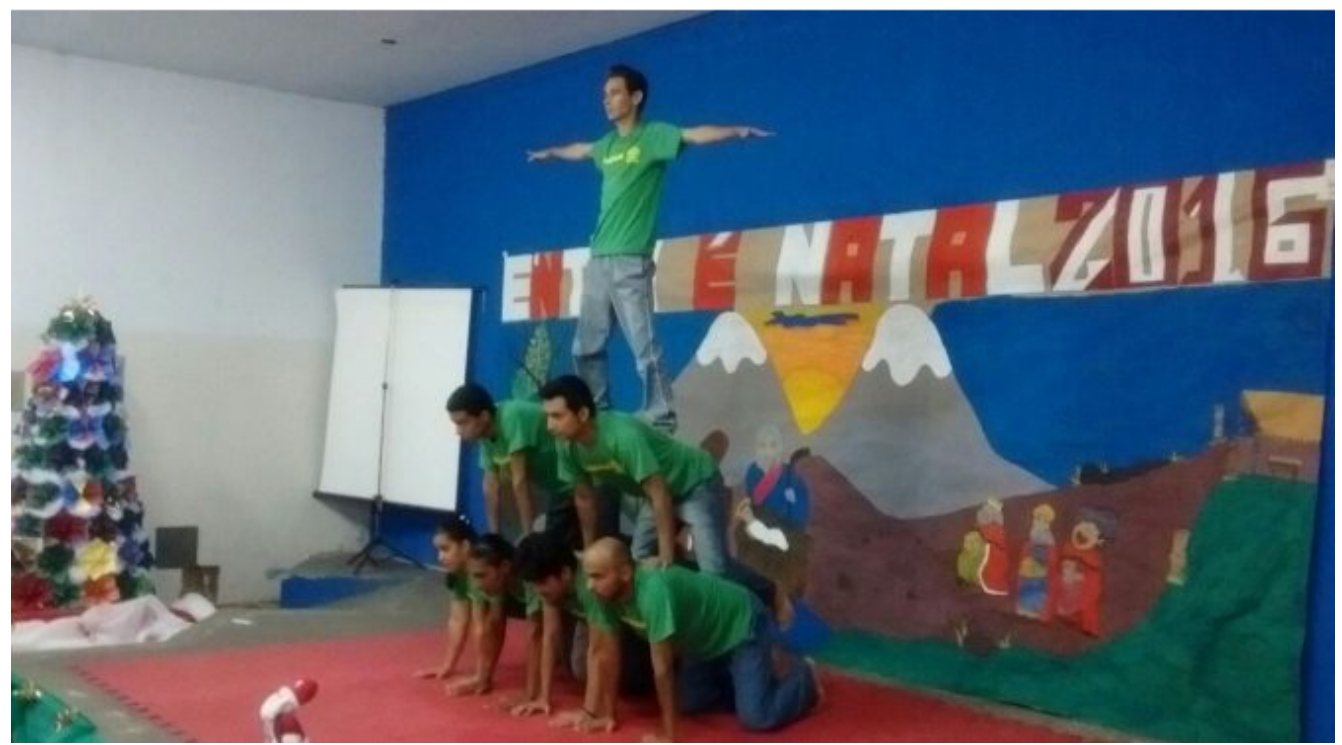

Fonte: AGEPEN (2015)

Figura 7 - Apresentação alunos do EPJFC encerramento do ano letivo 2016

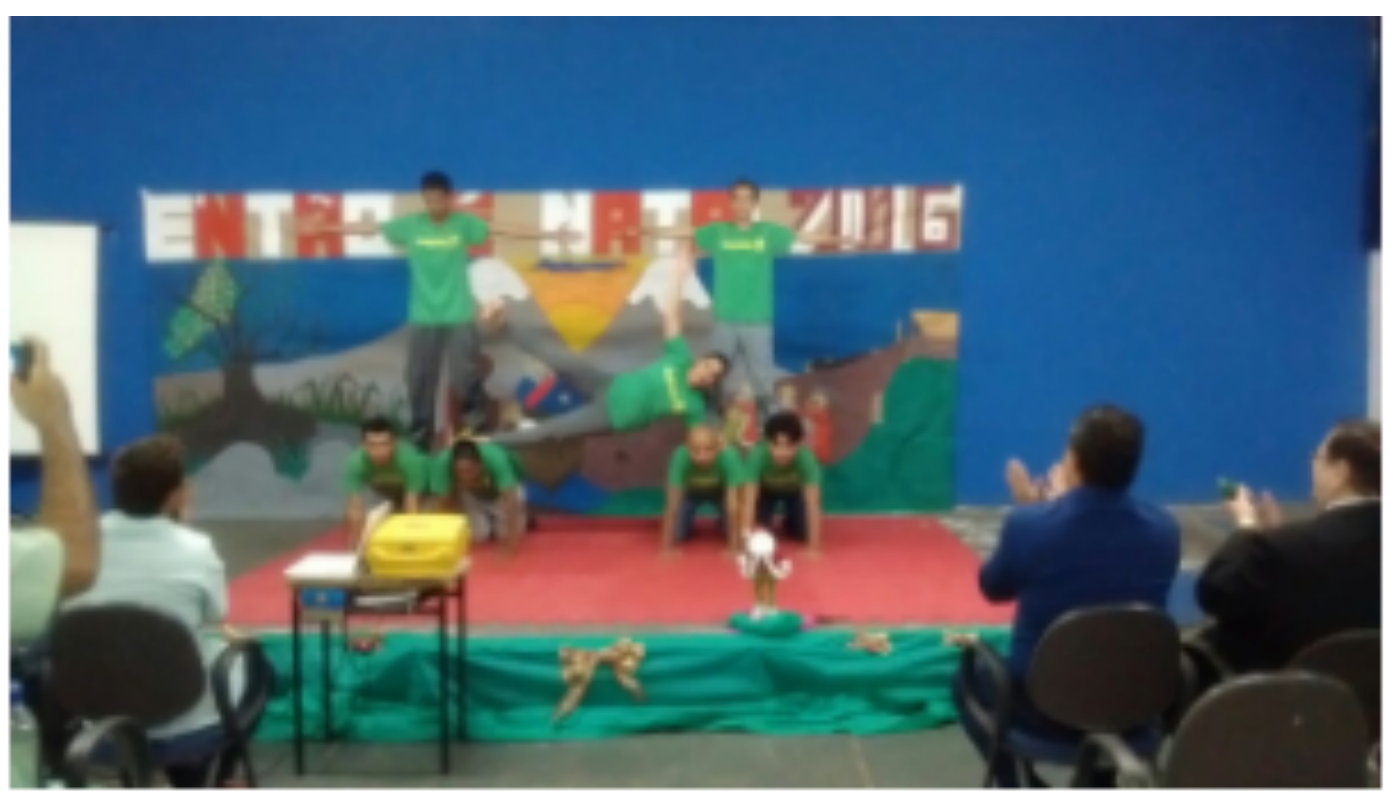

Fonte: AGEPEN (2015)

Nas figuras 6 e 7, visualizamos uma apresentação cultural voltada para a arte circense com a modalidade de acrobacias coletivas, sendo o corpo o elemento principal e pelo qual se desenvolvem as ações, delineadas por gestos, músicas, equilíbrios e atuações. Em volta disso o corpo encontra novas formas, constrói significações para os sujeitos. "É uma atividade que exerce grande fascínio [...] o 
corpo é o centro do espetáculo, de todas as "variedades" apresentadas pela multifacetada atuação de seus artistas." (Soares, 2005, p. 23).

No decorrer do tempo essas práticas são consideradas como movimentos que se opunham aos princípios de corpo acabado, que a ciência construirá de forma disciplinada, pois "[...] lançavam-se ao espaço, contorciam-se e encaixavamse em potes, em cestos, imitavam bichos, vozes, produziam sons com as mais diferentes partes do corpo, cuspiam fogo, vestiam roupas inesperados, gargalhavam" (Soares, 2005, p. 24). Nos espetáculos, o corpo é o ponto de partida para a realização dessas atividades circenses que fugiam das regras e que desafiam os limites do sujeito.

Figura 8 - Apresentação de quadrilha no IPCG

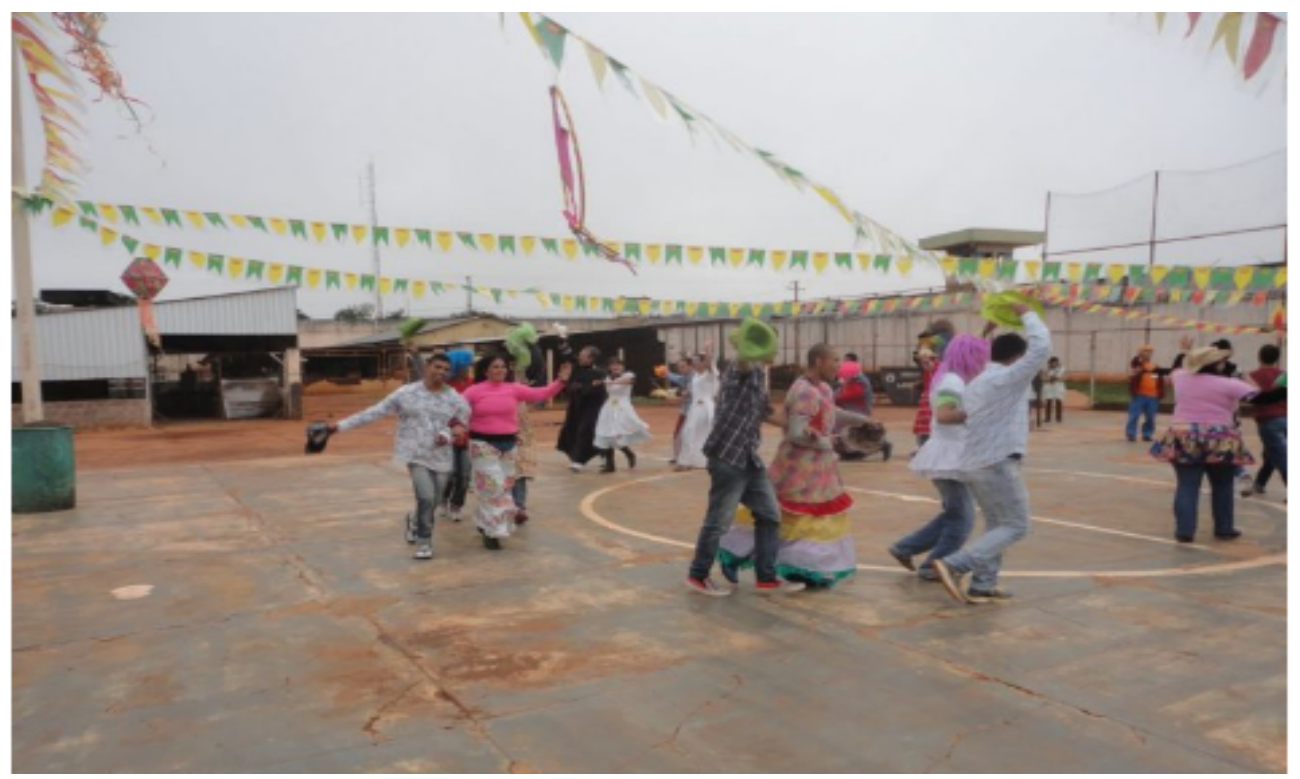

Fonte: Santinoni e Oliveira (2017)

Na figura 8, observamos uma dança folclórica de quadrilha no IPCG, onde pessoas em privação de liberdade utilizam de criatividade em suas vestimentas, além de demonstrar com a dança uma maior movimentação corporal, permitindo o contato próximos uns com os outros, embora estejam cercados por muros altos e torres de vigilância.

Quando esses sujeitos estão em contato com as artes cênicas, entram na contramão do que a sociedade pretende para o corpo social, que não permite os 
excessos. Para além desse entretenimento, essas atividades que encontramos estão mais alinhadas com práticas civilizadas de captura, reprodução e administração dos corpos. Vale ressaltar, entretanto, que o movimento que Foucault (2014) chama de disciplina, estava culturalmente presente, encontrando uma maneira de registro e transmissão de saberes e poderes.

As atividades corporais então, paulatinamente, são classificadas, analisadas e, meticulosamente, redesenhadas pelas mãos dos homens de ciência. Devem reaparecer no interior de um projeto científico, estético e, sobretudo, distante de seu núcleo primordial. Surgem, então, como o lado verdadeiro de um avesso que deve ser escondido, difamado, olhado com desconfiança porque vindo de um espaço que insiste em não enquadrar-se na metrificação e quantificação burguesa e científica. (Soares, 2005, p. 59).

Nesse sentido, as artes cênicas ainda se encontram em menor quantidade no que diz respeito ao trabalho de ressocialização desses sujeitos, e uma das justificativas para a pouca utilização dessas atividades, segundo relato de profissionais penitenciários durante visita às unidades penais investigadas, devese à superpopulação carcerária, falta de espaço físico adequado e número reduzido de servidores.

Devido ao uso de um poder que toma conta da vida dos indivíduos em privação de liberdade, estes sujeitos são conduzidos a terem comportamentos controlados por dispositivos e tecnologias encontradas no ambiente prisional, tais como vigilância constante, aparelhos detectores de metais, raio-X, scanner corporal, dentre outros mecanismos utilizados para que não haja muitas possibilidades de liberdade e que sejam mais voltados para trabalhos manuais, tal como a prática de artesanato.

Um ambiente permeado pelas disciplinas e, ao mesmo tempo, ocupado pelos sujeitos que realizam essas atividades, com atribuições em relação as instituições e sua rede de conexões que se configuram nos espaços garantindo a obediência, mas também o controle dos gestos, das atividades e do tempo desses sujeitos, colocando o corpo a prova na realização de práticas que assegurem a eficácia do trabalho proposto e criem sujeitos dóceis no ambiente prisional. 


\section{Considerações}

Durante a pesquisa percebemos que a não valorização e a falta de estímulo às atividades que contribuam para o desenvolvimento corporal das pessoas em privação de liberdade, deve-se à falta de estrutura física e de pessoal, pois, como demonstrado na figura 3, a extensão escolar do IPCG, por exemplo, tem espaço limitado. Além disso, percebemos que o que era antes espaço para prática de esportes, deu lugar a vários barracões para o desenvolvimento de atividades laborais, deixando o espaço reduzido e utilizado exclusivamente para festividades, como pode ser visto na figura 8.

Quanto ao nosso questionamento sobre as atividades consideradas artísticas serem mais individuais e manuais, como o artesanato, a pintura, a construção de brinquedos, notamos que não há interesse da instituição em desenvolver outras formas de motivação ou de aprendizagens voltadas para as artes cênicas, pois o discurso de poder e a imposição de disciplina acabam por podar qualquer tentativa de tornar a aula diferente. Como destaca Barcelos (2017, p. 111) ao transcrever entrevista a uma professora da Escola Betine, extensão de Corumbá-MS:

Donizete: Assim, ministrar as aulas não é o problema. O problema é você querer levar algo diferenciado. E aí tem aquela retaliação, você não pode, você tem que ficar tudo pisando em ovos ali para ver o quê que pode, você tem que estar pedindo autorização, "eu posso levar isso, eu posso fazer aquilo", a gente quer trabalhar com projetos, então não é tudo que é aceito.

P: E professora, você acha que esse "não ser aceito", ele é necessário mesmo pela segurança ou existe um exagero da parte do agente penitenciário?

Donizete: É, assim, eu não tenho medo de trabalhar com aqueles alunos. Eu acho que às vezes é sim um certo exagero, eu não sei se pode ser muita inocência da minha parte, porque eu sinto confiança, porque os alunos eles veem o professor com outros olhos, o professor não está ali para julgar ele do que ele fez, a gente está ali para ensinar. Então ele trata a gente de uma certa forma diferenciada, diferente dos agentes que eles já veem com maus olhos.

$\mathrm{P}: \mathrm{Sim}$.

Donizete: Então assim, para os agentes, eles são bandidos, e para nós não. É outra visão. Para nós, eles são alunos.

(Transcrição da entrevista realizada no dia 18 nov.2016). 
Dessa forma, fica evidente que o sistema penitenciário do estado de Mato Grosso do Sul promove atividades artísticas voltadas a geração de renda, a profissionalização e qualificação de mão de obra, deixando de valorizar o artista escondido em meio a grades e altos muros.

Também vimos que o interesse maior está em controlar o ambiente prisional e ocupar a mente e o corpo desses sujeitos evitando o ócio.

E, embora o artesanato produzido pelas pessoas em privação de liberdade seja valorizado e reconhecido pela sociedade, o foco e a atenção são direcionados mais para a quantidade e qualidade do material produzido, do que nos sujeitos que as criam.

Assim sendo, a ausência da prática de artes cênicas no contexto prisional configura-se por contradições na busca de desenvolvimento no âmbito da educação escolar, sendo dominada pelas conjunturas da instituição que segue certas normas e regras que precisam ser obedecidas, porém se perde a construção da autonomia, o estimulo a liberdade de expressão, pois o interesse maior não seria esse.

Contudo há toda uma discussão em torno da ressocialização sendo necessária a compreensão de seu significado no ambiente prisional para que seja efetivamente parte do desenvolvimento de cada indivíduo ali inserido, considerando que não se trata de nosso objeto de pesquisa.

Consideramos que por intermédio das artes cênicas é possível que sejam abertos novos olhares para esse contexto, onde a experiência e o contato com essas práticas provoquem inquietações e possíveis respiros e motivações dentro desse espaço prisional.

Acreditamos que este não é o fim, mas o começo de um olhar em direção ao delineamento da caminhada que propomos até aqui, sendo possível compor algumas considerações, mas sabendo que sempre haverá questionamentos e indagações que surgirão a partir das possibilidades, deslocamentos e ângulos que a temática for observada. 


\section{Referências}

AGEPEN. Diretoria de Operações. Núcleo de Informações Criminais. Mapa da População Carcerária da AGEPEN, jun./2019. Campo Grande: AGEPEN, 2019.

AGEPEN. Presídios encerram ano letivo com festas de natal. Publicado em 19 de dezembro de 2016. Disponível em: https://www.agepen.ms.gov.br/presidiosencerram-ano-letivo-com-festas-de-natal/. Acesso em 25 out. 2020.

ASSUMPÇÃO, Mariana de Cássia. As relações entre arte e vida em Lukács e Vigotski. Aspas: Araraquara, v. 4, n. 1, p.41-49, 2014.

BARCELOS, Clayton da Silva. Educação escolar na prisão: os significados e sentidos das professoras que atuam em unidades penais de Corumbá, Mato Grosso do Sul. 167 f. Dissertação (Mestrado em Educação) Universidade Federal de Mato Grosso do Sul, Corumbá/MS, 2017.

BRASIL. Constituição da República Federativa do Brasil de 1988. Disponível em: http://www.planalto.gov.br/ccivil_03/Constituicao/Constituicao.htm. Acesso em: 13 abr. 2020.

BRASIL. Departamento Penitenciário Nacional. Agência Estadual de Administração do Sistema Penitenciário. Projeto de Capacitação Profissional e Implantação de Oficinas Permanentes (PROCAP) junho, 2012. Brasília/DF: DEPEN, 2012.

CASTRO, Edgardo. Vocabulário de Foucault: um percurso pelos seus temas, conceitos e autores. Trad. Ingrid Müller Xavier; Rev. Téc. Alfredo Veiga-Neto e Walter Omar Kohan. 2. ed. Belo Horizonte: Autêntica Editora, 2016.

FOUCAULT, Michel. Microfísica do poder. 2. ed. Rio de Janeiro: Paz e Terra, 2015.431p.

FOUCAULT, Michel. Nascimento da Biopolítica: curso dado no Collège de France (1978-1979). Martins Fontes, 2008b.

FOUCAULT, Michel. Segurança, território, população: curso dado no Collège de France (1977-1978). Tradução de Eduardo Brandão. São Paulo: Martins Fontes, 2008 a.

FOUCAULT, Michel. Vigiar e Punir. Petrópolis: Vozes, 2014.

LIMA, Karina Medeiros. Fundação de Cultura entrega carteira nacional do artesão para internas do presídio feminino. Publicado em 26 de junho de 2015. Disponível em: $\quad$ https://www.agepen.ms.gov.br/fundacao-de-cultura-entrega-carteiranacional-do-artesao-para-internas-do-presidio-feminino/. Acesso em: 10 out. 2020. 
MATO GROSSO DO SUL. Decreto-Lei n. 11, de 10 de janeiro de 1979a. Dispõe sobre o Sistema Estadual de Justiça, autoriza a criação da entidade que menciona e dá outras providências. Disponível em: http://aacpdappls.net.ms.gov.br/appls/legislacao/secoge/govato.nsf/c19b1c307bc 93729042571070059deab/961839ce9b3ab85b04256e8b006e6961?OpenDocument . Acesso em: 20 mar. 2019.

MATO GROSSO DO SUL. Decreto n. 26 de 10 de janeiro de 1979b. Estabelece a competência, aprova a estrutura básica do Departamento do Sistema Penitenciário de Mato Grosso do Sul (DSP) e dá outras providências. Disponível em: http://aacpdappls.net.ms.gov.br/appls/legislacao/secoge/govato.nsf/fd8600de8a5 5c7fc04256b210079ce25/7e6c33a9b396d29d04256e2d0065d6fa?OpenDocument. Acesso em: 2 out. 2019.

MATO GROSSO DO SUL. Decreto n. 11.514, de 22 de dezembro de 2003. Cria a Escola Estadual Polo Prof.a Regina Lúcia Anffe Nunes Betine, com sede no Município de Campo Grande, e dá outras providências. Disponível em: http://aacpdappls.net.ms.gov.br/appls/legislacao/secoge/govato.nsf/fd8600de8a5 5c7fc04256b210079ce25/b0d9f98fcd89357e04256e050053af90?OpenDocument\& Highlight=2,11.514. Acesso em: 28 mar. 2020.

MATO GROSSO DO SUL. Poder Judiciário do Estado de Mato Grosso do Sul. Comarca de Campo Grande. Primeira Vara de Execução Penal. Portaria no 1/2018, da Primeira Vara de Execução Penal de Campo Grande, de 23 de abril de 2018. Estabelece e disciplina a implantação de projeto de remição pela leitura, prática recomendada pelo Conselho nacional de Justiça. Cartório da Primeira Vara de Execução Penal. MM. Juiz de Direito Dr. Caio Marcio de Britto.

MATO GROSSO DO SUL. Secretaria de Estado de Educação. Resolução/SED n. 1.714, de 27 de fevereiro de 2004. Dispõe sobre a Autorização de Funcionamento do Ensino Fundamental e do Ensino Médio na Escola Estadual Pólo Profa. Regina Lúcia Anffe Nunes Betine, com sede no município de Campo Grande/MS. Disponível em: http://aacpdappls.net.ms.gov.br/appls/legislacao/sed/legased.nsf/e3258672435f3 90e04257134005057a1/4ec86c5fbed6285104257248004199d8?OpenDocument.

Acesso em: 14 abr. 2020.

MATO GROSSO DO SUL. Lei n. 4.490, de 3 de abril de 2014b. Dispõe sobre a reorganização da carreira Segurança Penitenciária, integrada por cargos efetivos do Grupo Segurança do Plano de Cargos, Empregos e Carreiras do Poder Executivo; reestrutura o Quadro de Pessoal da Agência Estadual de Administração do Sistema Penitenciário do Estado de Mato Grosso do Sul (AGEPEN-MS), e dá outras providências. Disponível em: http://aacpdappls.net.ms.gov.br/appls/legislacao/secoge/govato.nsf/448b683bce4 ca84704256c0b00651e9d/b723c3cb94b6cf0804257cb30066db50?OpenDocumen t. Acesso em: 30 jul. 2020.

MATO GROSSO DO SUL. Lei n. 4.640, de 24 de dezembro de 2014a. Reorganiza a 
Estrutura Básica do Poder Executivo do Estado de Mato Grosso do Sul, e dá outras providências.

Disponível

em:

http://aacpdappls.net.ms.gov.br/appls/legislacao/secoge/govato.nsf/448b683bce4 ca84704256c0b00651e9d/8ff816bc6ca622d504257dbd00412234?OpenDocument\& Highlight=2,4.640. Acesso em: 18 abr. 2020.

MATO GROSSO DO SUL. Secretaria de Estado de Educação. Secretaria de Estado de Justiça e Segurança Pública. Plano Estadual de Educação nas Prisões do estado de Mato Grosso do Sul. Campo Grande, agosto 2015.

MATO GROSSO DO SUL. Secretaria de Estado de Justiça e Segurança Pública. Coordenadoria de Políticas Penitenciárias. Relatório Situação Carcerária, fevereiro/2019. Campo Grande/MS: 2019.

MÁXIMO, Maria José. Arte e formação humana: Contribuições do Marxismo. V encontro brasileiro de educação e marxismo, abril UFSC, Florianópolis, 2011.

OLIVEIRA, Keila Terezinha. Governo disponibiliza mais 1,3 mil tornozeleiras para atendimento às determinações judiciais em MS. Publicado em 26 de março de 2018. Disponível em: http://www.agepen.ms.gov.br/governo-contrata-mais-13-miltornozeleiras-para-atendimento-as-determinacoes-judiciais-em-ms/. Acesso em: 27 jun. 2019.

OLIVEIRA, Keila Terezinha Rodrigues de. Artesanatos produzidos em presídios da Capital e de Corumbá são expostos ao público no Festival América do Sul. Publicado em 21 de agosto de 2015. Disponível em: https://www.agepen.ms.gov.br/artesanato-produzido-em-presidios-da-capital-ede-corumba-sao-expostos-ao-publico-no-festival-america-do-sul/. Acesso em: 6 out. 2020.

OLIVEIRA, Keila Terezinha Rodrigues de. Feira de artesanatos feitos em presidios inicia nesta segunda-feira. Publicado em 5 de dezembro de 2016a. Disponível em: https://www.agepen.ms.gov.br/artesanatos-confeccionados-em-presidios-seraoexpostos-para-venda-no-forum-da-capital-2/. Acesso em: 10 out. 2020.

OLIVEIRA, Keila Terezinha Rodrigues de. Arte do mosaico profissionaliza e serve como terapia para reeducandas do presídio feminino de Campo Grande. Publicado em 12 de dezembro de 2016b. Disponível em: https://www.agepen.ms.gov.br/artedo-mosaico-profissionaliza-e-serve-como-terapia-para-reeducandas-dopresidio-feminino-de-campo-grande/. Acesso em: 8 out. 2020.

OLIVEIRA, Keila Terezinha Rodrigues de. Oficina de artesanato ocupa e profissionaliza detentas no presídio feminino de Campo Grande. Publicado em 3 de março de 2017. Disponível em: https://www.agepen.ms.gov.br/oficina-deartesanato-ocupa-e-profissionaliza-detentas-no-presidio-feminino-de-campogrande/. Acesso em: 4 out. 2020.

OLIVEIRA, Keila Terezinha Rodrigues de. Internos do IPCG participam amanhã de 
capacitação em técnicas de decoupage e artesanato em barbante. Publicado em 18 de novembro de 2018. Disponível em: https://www.agepen.ms.gov.br/internosdo-ipcg-participam-amanha-de-capacitacao-em-tecnicas-de-decoupage-eartesanato-em-barbante/. Acesso em: 5 out. 2020.

OLIVEIRA, Keila Terezinha Rodrigues. Com mão de obra prisional, "Arte com Pneus" contempla a 15a instituição infantil de ensino e realiza desejo de alunos" Publicado em 30 de agosto de 2019a. Disponível em: https://www.agepen.ms.gov.br/commao-de-obra-prisional-arte-com-pneus-contempla-a-15a-instituicao-infantilde-ensino-e-realiza-desejo-de-alunos/. Acesso em: 05 out. 2020.

OLIVEIRA, Keila Terezinha Rodrigues de. De embalagens de frutas a big bags de açúcar, descartes viram produto de moda e utilitários nas mãos de detentas. Publicado em 9 de dezembro de 2019b. Disponível em: https://www.agepen.ms.gov.br/de-embalagens-de-frutas-a-big-bags-de-acucardescartes-viram-produto-de-moda-e-utilitarios-nas-maos-de-detentas/. Acesso em: 5 out. 2020.

OLIVEIRA, Keila Terezinha Rodrigues de. Projeto realizado em presídio ajuda no combate à dengue e leva educação lúdica a crianças. Publicado em 29 de abril de 2019. Disponível em: https://www.agepen.ms.gov.br/projeto-realizado-empresidio-ajuda-no-combate-a-dengue-e-leva-educacao-ludica-a-criancas/.

Acesso em: 5 out. 2020.

OsÓRIO, Antônio Carlos do Nascimento (org.). Sujeito e instituições: pensando em Michel Foucault. Campo Grande: Oeste, 2019.

OSÓRIO, Antônio Carlos do Nascimento. As instituições: discursos, significados e significantes, buscando subsídios teóricos e metodológicos. In: OsóRIO, Antônio Carlos do Nascimento. Diálogos em Foucault. Campo Grande: Oeste, 2010.p.95133.

OSÓRIO, Antônio Carlos do Nascimento. Estranho medo da inclusão. Educação, v. 32, n. 2, p. 301-318, 2007.

SANTINONI, Tatyane Oliveira. "Com foco na ressocialização, tradição, cultura e educação são incentivadas em presídios de MS". Publicado em 18 de julho de 2019. Disponível em: https://www.agepen.ms.gov.br/comemoracoes-caipiras-inspiramespontaneidade-e-levam-reeducandos-de-ms-a-expressarem-sentimentos/ Acesso em: 05 out. 2020.

SANTINONI, Tatyane Oliveira. "Tecido de Afeto e Cura": Com teatro e poesia, reeducandas da capital descobrem um novo olhar para a educação. AGEPEN, Campo Grande, 28 ago. 2019. Disponível em: https://www.agepen.ms.gov.br/tecido-de-afeto-e-cura-com-teatro-e-poesiareeducandas-da-capital-descobrem-um-novo-olhar-para-a-educacao/. Acesso em: 05 out. 2020. 
SANTINONI, Tatyane; Oliveira, Keila. No Dia Mundial do Livro, Leitura é sinônimo de liberdade para quem está na prisão. Publicado em 23 de abril de 2018. Disponível em: https://www.agepen.ms.gov.br/no-dia-mundial-do-livro-leitura-e-sinonimode-liberdade-para-quem-esta-na-prisao/. Acesso em: 27 jun. 2019.

SANTINONI, Tatyane; OLIVEIRA, Keila. Presentes no calendário cultural, festas caipiras também proporcionaram interação e harmonia em presídios do MS. Publicado em 4 de julho de 2017. Disponível em: https://www.agepen.ms.gov.br/presentes-no-calendario-cultural-festas-caipirastambem-proporcionaram-interacao-e-harmonia-em-presidios-do-ms/. Acesso em 25 out. 2020.

SILVA, Eliana Doraci da. A Constituição da Escola Estadual Polo Profe Regina Lúcia Anffe Nunes Betine: práticas pedagógicas nos presídios masculinos de regime fechado. Anais do V Congresso de Educação da Grande Dourados FAED/UFGD. Evento de 07 a 10 de outubro, 2019a. Dourados-MS.

SILVA, Eliana Doraci da. OSÓRIO, Antônio Carlos do Nascimento. Caminhos Percorridos pela Educação no Instituto Penal de Campo Grande. In: VIII Encontro dos Programas de Pós-Graduação em Educação de Mato Grosso do Sul "Perspectivas para a Política Educacional e a Formação Docente". VIII Encontro de Políticas e Práticas de Formação de Professores. IV Seminário da Associação Nacional de Política e Administração da Educação (ANPAE/MS). IV Encontro Estadual da Associação Nacional pela Formação dos Profissionais da Educação (ANFOPE/MS). 18 a 20 de novembro de 2019b, UFGD - Dourados/MS.

SOARES, Carmem Lúcia. Imagens da educação no corpo: estudo a partir da ginástica francesa no século XIX. 3. ed. Campinas, São Paulo: Autores Associados, 2005.

Recebido em: 15/10/2020

Aprovado em: 02/12/2020 